\title{
PEMEDIASIAN SELF-EFFICACY ANTARA UNIVERSITY ENVIRONMENT SUPPORT DAN ENTREPRENEURIAL INTENTION PADA MAHASISWA PROGRAM BISNIS ENTREPRENEURSHIP
}

\author{
Krismi Budi Sienatra ${ }^{1)}$, Natalia Pangestu ${ }^{2)}$ \\ 1)Fakultas Manajemen dan Bisnis, Universitas Ciputra \\ 2)Fakultas Manajemen dan Bisnis, Universitas Ciputra \\ Mail: krismi.budi@ciputra.ac.id
}

\begin{abstract}
The high number of demographic bonus in Indonesia does not match the number of entrepreneurs in that country. Indonesia has the lowest percentage of entrepreneurs compared to other countries. One of the ways to increase the number percentage of entrepreneurs in Indonesia is to create an entrepreneur especially through students. The intention of students in entrepreneurship can be increased through the support that is given by the university. The main purpose of learning to attempt to create a young entrepreneur in the community environment through problem and project-based-learning system that is trusted to be able to increase student's self-efficacy and entrepreneurial intention. Therefore, the purpose of this research is to find out the effect of university environment support on entrepreneurial intention through self-efficacy as mediation. This research uses quantitative approach by using Partial Least Square. The sampling technique that is used is random sampling with the total sample of 82 final year students. The research results show that university environment support does not affect significant on entrepreneurial intention, university environment support affects significant on self-efficacy, self-efficacy affects significant on entrepreneurial intention, self-efficacy mediates the effect of university environment support and students' entrepreneurial intention.
\end{abstract}

Keywords: University Environment Support, Self-Efficacy, Entrepreneurial Intention

\begin{abstract}
ABSTRAK
Tingginya angka bonus demografi di Indonesia tidak sesuai dengan jumlah wirausaha di negara tersebut. Indonesia memiliki jumlah presentase wirausaha terendah dibandingkan negara lain. Salah satu cara untuk dapat meningkatkan jumlah presentase wirausaha di Indonesia adalah dengan menciptakan seorang wirausaha khususnya melalui mahasiswa. Intensi mahasiswa dalam berwirausaha dapat ditingkatkan melalui dukungan yang diberikan oleh universitas. Tujuan utama pembelajaran yang diberikan universitas adalah berusaha menciptakan seorang wirausaha muda di lingkungan masyarakat melalui sistem pembelajaran problem and project-based-learning yang dipercaya mampu menumbuhkan self-efficacy dan entrepreneurial intention mahasiswa. Oleh karena itu, penelitian ini bertujuan untuk mengetahui pengaruh university environment support terhadap entrepreneurial intention melalui self-efficacy sebagai mediasi. Penelitian ini menggunakan pendekatan kuantitatif dengan menggunakan Partial Least Square. Teknik sampling yang digunakan adalah random sampling dengan jumlah sampel sebanyak 82 mahasiswa tingkat akhir. Hasil penelitian menunjukkan bahwa university environment support tidak berpengaruh secara signifikan terhadap entrepreneurial intention, university environment support berpengaruh secara signifikan terhadap self-efficacy, self-efficacy berpengaruh secara signifikan terhadap entrepreneurial intention, self-efficacy memediasi pengaruh university environment support dan entrepreneurial intention mahasiswa.
\end{abstract}

Kata kunci: University Environment Support, Self-Efficacy, Entrepreneurial Intention

\footnotetext{
*Korespondensi Penulis

E-mail: krismi.budi@ciputra.ac.id
} 


\section{PENDAHULUAN}

Jumlah penduduk Indonesia pada tahun 2020 diproyeksikan berjumlah 271,066,400 jiwa dengan jumlah bonus demografi sebanyak 185,34 juta jiwa. Tingkat pengangguran di Indonesia pada Agustus 2019 mencapai 7,05 juta dari 133,56 juta jiwa. Menurut Kusmintarti et al., (2017) mengatakan bahwa orang-orang lebih memilih untuk menjadi job seeker dibanding menjadi job creator sehingga hal ini dapat menyebabkan meningkatnya jumlah pengangguran di Indonesia. Salah satu cara untuk dapat mengatasi tingkat pengangguran di Indonesia adalah dengan menanamkan jiwa kewirausahaan pada diri seseorang (Liputan6.com, 2019). Seorang wirausaha pastinya dapat mendirikan usahanya sendiri dan membuat lapangan pekerjaan bagi orang lain. Pada tahun 2015, jumlah wirausahawan di Indonesia meningkat dari $1,6 \%$ menjadi $3,1 \%$ dari keseluruhan jumlah populasi pada saat itu (Kominfo, 2017). Angka ini menunjukkan bahwa Indonesia telah memenuhi standar internasional yaitu $2 \%$ dari populasi, akan tetapi Indonesia masih berada di presentase terendah dibanding negara lain.

Penyebab rendahnya presentase di Indonesia karena kurangnya dukungan dari sistem pendidikan yang dapat membentuk mahasiswa untuk menjadi seorang pengusaha. Kebanyakan dari mereka yang telah mendapatkan gelar sarjana lebih memilih untuk melamar menjadi aparatur sipil negara dibandingkan berwirausaha (Zuraya, 2018). Bonus demografi yang besar dari usia produktif di Indonesia dapat menjadi hal positif dan hal negatif. Hal negatif terjadi dimana pemerintah harus menyediakan sejumlah besar lapangan pekerjaan agar mampu menyerap golongan usia produktif ini dan jika ketersediaan lapangan pekerjaan lebih sedikit akan menimbulkan ketimpangan dan munculnya pengangguran. Hal positif dari bonus demografi ini jika lebih banyak dari golongan usia produktif ini berwirausaha dan menciptakan lapangan pekerjaan. Hamdani (2018), dari hasil survey yang telah mereka lakukan pada mahasiswa di salah satu kampus di Indonesia, menunjukkan bahwa $61,5 \%$ dari mereka memiliki niat dalam berwirausaha dan sebagian besar dari mereka telah memiliki usaha kecil yang mereka jalankan pada saat berkuliah. Bisnis usaha yang dirintis ketika masa berkuliah kebanyakan karena merupakan bagian dari kurikulum pendidikan jurusan bisnis.
Percepatan dalam membentuk minat berwirausaha atau entrepreneurial intention sejak masa berkuliah perlu didorong dan difasilitasi oleh universitas yang menyediakan fasilitas fisik dan non fisik untuk mahasiswa dalam menumbuhkan, merintis dan pada akhirnya mengembangkan bisnis mereka. Peranan ini disebut dengan university environement support dipercaya mempunyai peran yang cukup penting dalam membentuk pola berpikir dan self-efficacy mahasiswa dalam meningkatkan entrepreneurial intention. Universitas dapat menyediakan program inkubator bisnis untuk mendukung terciptanya selfefficacy guna meningkatkan entrepreneurial intention (Surya \& Sitepu, 2019). Menurut Hartono \& Puspitowati (2019) peningkatan entrepreneurial intention mahasiswa mengacu pada Theory of Planned Behavior yang terdiri dari attitude, subjective norms, dan self-efficacy.

Self-efficacy merupakan variabel yang penting dalam mempengaruhi entrepreneurial intention seseorang, karena variabel ini merupakan bentuk seorang individu percaya pada kemampuannya sendiri dalam melakukan suatu tindakan yaitu berwirausaha. Pada dasarnya, seseorang harus dapat mengawali suatu tindakan yang akan diperbuat melalui kepercayaan dirinya karena hal ini yang akan menentukan seseorang tersebut untuk bertindak atau tidak pada suatu hal seperti halnya berwirausaha. Hal ini menunjukkan bahwa seseorang harus memiliki self-efficacy untuk dapat memiliki intensi dalam berwirausaha (Vanessa \& Sienatra, 2020). Self-efficacy seseorang dibentuk melalui dukungan yang telah diberikan oleh university environment support melalui pembelajaran dan praktik yang telah diberikan.

Universitas yang mengutamakan pendidikan entrepreneurship sebagai tujuan utama pembelajaran bagi mahasiswa perlu membentuk lingkungan yang mendukung setiap aktivitas pembelajaran entrepreneurship. Hal ini yang disebut dengan university environment support yang berfungsi meningkatkan self-efficacy mahasiswa salah satunya dapat melalui project-based-learning dalam mata kuliah entrepreneurship. Mata kuliah tersebut menyediakan pembelajaran sekaligus praktik terkait entrepreneur. Pelaksanaan proses pembelajaran harus didukung dengan kegiatan praktik sebagai upaya untuk meningkatkan selfefficacy dan intensi seseorang (Kusmintarti et al., 2017) 
Cara pertama meningkatkan kepercayaan diri individu yang dilakukan pembelajaran entrepreneurship berupa mentoring. Mentoring adalah kegiatan diskusi antara seseorang yang lebih berpengalaman dan berpengetahuan lebih dengan seseorang yang kurang berpengalaman dan berpengetahuan sedikit. Yang kedua adalah membantu memperluas network mahasiswa. Tujuan dari network adalah untuk membantu mengembangkan bisnis yang ada (Sienatra \& Padmalia, 2018) melalui dukungan yang diberikan diharapkan dapat menumbuhkan self-efficacy mahasiswa. Dengan adanya self-efficacy pada diri seseorang dapat meningkatkan entrepreneurial intention mereka. Penelitian ini bertujuan untuk mengetahui pengaruh university environement support terhadap entrepreneurial intention melalui self-efficacy yang dibentuk selama proses pembelajaran pada mahasiswa bisnis.

\section{Tinjauan Literatur}

\section{Theory of Planned Behavior (TPB)}

Perilaku masa depan yang dapat dilakukan oleh seseorang didahului oleh niat: semakin kuat niat seseorang untuk terlibat dalam perilaku tertentu, maka semakin besar kemungkinannya bahwa perilaku yang sebenarnya akan dilakukan di masa yang akan datang (Fauzani et al., 2019). Theory of Planned Behavior (TPB) terdiri dari tiga unsur kognitif yaitu: 1) attitude towards behavior, 2) subjective norms, dan 3) perceived behavior control (Ajzen, 1991). Attitude towards behavior adalah suatu tindakan dimana seorang individu dapat menilai sikap mereka yang nantinya dapat menentukan dirinya dalam berperilaku, subjective norms adalah suatu pengaruh dari lingkungan sosial yang menentukan seseorang dalam bertindak untuk melakukan atau tidak melakukan suatu perilaku, dan perceived behavior control adalah seseorang tidak dapat sepenuhnya mengontrol perilaku yang mereka lakukan karena dapat dipengaruhi oleh beberapa faktor seperti dukungan dari diri sendiri dan lingkungan sekitar

University environment support adalah persepsi mahasiswa terkait peran universitas dalam mendukung entrepreneurial intention mahasiswa (Soria-Barreto et al., 2017). University environment support juga berperan dalam pengembangan entrepreneurial intention terhadap Pendidikan kewirausahaan, program inkubator bisnis, mentoring, networking, budaya dan infrastruktur, serta sebagai sumber daya universitas (Shirokova et al., 2016)

Menurut (Trivedi, 2016) indikator university environment support meliputi 7 hal yaitu membawa siswa wirausaha berhubungan satu sama lain, menawarkan pekerjaan proyek yang berfokus pada kewirausahaan, menawarkan studi magang dalam kewirausahaan, menawarkan kursus elektif tentang kewirausahaan, menawarkan studi sarjana atau master dalam kewirausahaan, mengatur konferensi dan lokakarya tentang kewirausahaan, menyelenggarakan kompetisi rencana bisnis dan pengajaran kasus untuk kewirausahaan.

Self-efficacy merupakan keyakinan terhadap kemampuan seseorang meliputi kepercayaan diri, kemampuan menyesuaikan diri dan kapasitas bertindak pada situasi yang penuh dengan tekanan (Suseno, 2012). Kinerja seseorang dapat didorong melalui efikasi diri (Wulandari, 2013). Orang dengan efikasi diri yang tinggi akan berusaha dengan lebih maksimal untuk dapat menguasai suatu tantangan (Robbins \& Judge, 2013). Indikator selfefficacy meliputi Kepercayaan diri, Berani mengambil resiko, Kebutuhan pencapaian, Kemampuan dalam menghadapi situasi (Gelaidan \& Abdullateef, 2017)

Entrepreneurial intention adalah seorang wirausaha yang cenderung untuk menciptakan sebuah bisnis dengan memanfaatkan peluang yang ada (Krismi Budi Sienatra, 2020). Minat berwirausaha merupakan bentuk focus seseorang terhadap wirausaha karena adanya rasa suka dan disertai keinginan mempelajari dan mengetahui (Mustofa,2014). Menurut Trivedi (2016) menyatakan bahwa niat berwirausaha adalah tindakan yang direncanakan untuk melakukan perilaku kewirausahaan.

\section{Penelitian Terdahulu}

Wati et al., (2019) melakukan penelitian dengan variabel pengaruh lingkungan kampus, pembelajaran kewirausahaan, dan keinginan berwirausaha pada mahasiswa-di Indonesia. Hasil penelitian menunjukkan tidak ada pengaruh antara lingkungan kampus terhadap keinginan berwirausaha tetapi terdapat pengaruh pembelajaran kewirausahaan terhadap keinginan berwirausaha. Penelitian kedua adalah penelitian Hartono \& Puspitowati (2019) dengan variabel theory of planned bevahior dan intensi berwirausaha pada 
mahasiswa di Indonesia. Hasil penelitian menunjukkan attitude dan self-efficacy memiliki pengaruh terhadap intensi berwirausaha sedangkan subjective norms tidak memiliki pengaruh. Penelitian ketiga adalah penelitian Santy et al. (2017) dengan variabel theory of planned behavior, pendidikan kewirausahaan dan intensi berwirausaha pada mahasiswa di Indonesia. Hasil penelitian menunjukkan efikasi diri, norma subjektif, sikap berperilaku dan Pendidikan kewirausahaan berpengaruh terhadap intensi berwirausaha. Penelitian keempat adalah penelitian (Puspitaningtyas, 2017) dengan variabel efikasi diri, pengetahuan manajemen keuangan bisnis dan intensi berwirausaha pada mahasiswa di Indonesia. Hasil penelitian menunjukkan adanya pengaruh antara efikasi diri dan intensi berwirausaha namun tidak ada pengaruh dari pengetahuan manajemen keuangan bisnis.

Penelitian kelima adalah penelitian Surya \& Sitepu (2019) dengan variabel university environment support, theory of planned behavior dan entrepreneurial intention pada mahasiswa generasi milenial. Hasil penelitian menunjukkan adanya pengaruh antara university environment support dan entrepreneurial intention. Attitude towards behavior memediasi pengaruh university environment support terhadap entrepreneurial intention namun self-efficacy tidak memediasi pengaruh tersebut. Penelitian keenam adalah penelitian (Gelaidan \& Abdullateef, 2017) dengan variabel self-confidence, educational and relation support dan entrepreneurial intention. Hasil penelitian menunjukkan entrepreneurial intention berpengaruh terhadap educational support, relational support berpengaruh terhadap entrepreneurial intention dan self-confidence tidak berpengaruh pada variabel-variabel tersebut. Penelitian terakhir adalah penelitian (Trivedi, 2016) dengan variabel university environment support, theory of planned behavior dan entrepreneurial intention. Hasil penelitian menunjukkan adanya perbedaan antara para siswa India, Singapura dan Malaysia.

\section{Hipotesis}

Trivedi (2016) menggunakan variabel university environment support terhadap selfefficacy pada penelitiannya di India, Malaysia dan Singapura. Surya \& Sitepu (2019) menggunakan variabel yang sama untuk meneliti pada universitas "X". Penelitian tersebut menunjukkan hasil yang signifikan sehingga hipotesis yang dibangun dalam penelitian ini adalah:

H1: University environment support berpengaruh terhadap self-efficacy pada mahasiswa manajemen bisnis.

Rizki \& Megawati (2019) melakukan penelitian yang sama pada obyek mahasiswa yang juga menunjukkan hasil yang signifikan. Hasil berbeda juga bisa ditemukan yang menunjukkan hasil yang tidak signifikan pada mahasiswa (Wati et al., 2019). Hipotesis yang dibangun dalam penelitian ini adalah:

H2: University environment support berpengaruh terhadap entrepreneurial intention pada mahasiswa manajemen bisnis.

Oktaviana \& Umami, (2018) menggunakan variabel self-efficacy terhadap entrepreneurial intention pada siswa SMK. Khotimah et al., (2017) juga menunjukkan hasil yang signifikan ketika obyeknya mahasiswa. Hipotesis yang dibangun dalam penelitian ini adalah:

H3: Self-efficacy berpengaruh terhadap entrepreneurial intention pada mahasiswa manajemen bisnis.

Trivedi (2016) melakukan penelitian yang menunjukkan bahwa self-efficacy memediasi pengaruh university environment support terhadap entrepreneurial intention. Surya \& Sitepu (2019) menunjukkan bahwa self-efficacy tidak memediasi pengaruh university environment support terhadap entrepreneurial intention pada mahasiswa. Hipotesis yang dibangun dalam penelitian ini adalah:

H4: University environment support berpengaruh terhadap entrepreneurial intention melalui mediasi self-efficacy pada mahasiswa manajemen bisnis.

\section{METODOLOGI PENELITIAN}

Penelitian ini menggunakan metode kuantitatif. Populasi dari penelitian ini adalah 
mahasiswa yang tergabung pada program studi Manajemen bisnis berbasiskan entrepreneurship sebanyak 139 orang. Jumlah mahasiswa tersebut adalah mahasiswa yang telah berada di semester 7 dimana mereka harus diwajibkan menyelesaikan kurikulum pembelajaran entrepreneurship dari semester 1 hingga semester 6. Sampel yang dipilih menggunakan metode sensus dimana keseluruhan populasi dijadikan sampel. Kuesioner penelitian disebar selama jangka waktu dua minggu kepada obyek penelitian untuk mengisi kuesioner dan direkapitulasi. Sampel akhir berjumlah 82 orang dimana dari kuesioner yang disebar kembali dengan utuh.

\section{Variabel dan Definisi Operasional}

Tabel 1. Variabel dan Definisi Operasional

\begin{tabular}{|c|c|c|}
\hline Variabel & Definisi Operasional & Sumber \\
\hline \multirow{7}{*}{$\begin{array}{l}\text { University Environment } \\
\text { Support } \\
\text { persepsi mahasiswa } \\
\text { terkait peran universitas } \\
\text { dalam mendukung } \\
\text { entrepreneurial } \\
\text { intention mahasiswa } \\
\text { (Soria-Barreto } \text { et al., } \\
\text { 2017). }\end{array}$} & $\begin{array}{l}\text { Tersedia akademis yang memiliki pengetahuan terkait } \\
\text { entrepreneurship }\end{array}$ & \multirow{7}{*}{$\begin{array}{l}\text { Surya \& Sitepu } \\
\text { (2019); Trivedi } \\
(2016)\end{array}$} \\
\hline & $\begin{array}{l}\text { Mempengaruhi pertumbuhan dan perkembangan seseorang melalui } \\
\text { proses pembelajaran berbasis entrepreneurship }\end{array}$ & \\
\hline & Adanya dukungan network untuk membangun bisnis & \\
\hline & $\begin{array}{l}\text { Adanya praktik berupa eksekusi bisnis yang dapat menambah } \\
\text { pengalaman mahasiswa dalam berwirausaha }\end{array}$ & \\
\hline & $\begin{array}{l}\text { Menumbuhkan prinsip serta kepercayanan diri seseorang melalui } \\
\text { mentoring }\end{array}$ & \\
\hline & $\begin{array}{l}\text { Memotivasi mahasiswa untuk merintis bisnis baru melalui tahap } \\
\text { mentoring }\end{array}$ & \\
\hline & $\begin{array}{l}\text { Menciptakan kesadaran akan kewirausahaan sebagai sebuah pilihan } \\
\text { karier }\end{array}$ & \\
\hline \multirow{7}{*}{$\begin{array}{l}\text { Self-Efficacy adalah } \\
\text { keyakinan akan seluruh } \\
\text { kemampuan seseorang } \\
\text { meliputi kepercayaan } \\
\text { diri, kemampuan } \\
\text { menyesuaikan diri, } \\
\text { kecerdasan dan } \\
\text { kapasitas }\end{array}$} & Memiliki kontrol atas diri sendiri dalam berwirausaha & \multirow{7}{*}{$\begin{array}{l}\text { Gelaidan \& } \\
\text { Abdullateef (2017); } \\
\text { Trivedi (2016) }\end{array}$} \\
\hline & Memiliki komitmen yang tinggi dalam berwirausaha & \\
\hline & Memiliki kematangan mental dalam berwirausaha & \\
\hline & Memiliki motivasi yang kuat dalam berwirausaha & \\
\hline & Memiliki keyakinan pada kemampuan dalam berwirausaha & \\
\hline & Berani dalam mengambil resiko dalam berwirausaha & \\
\hline & $\begin{array}{l}\text { Memiliki rasa percaya diri akan kemampuan dalam memulai dan } \\
\text { mengelola bisnis }\end{array}$ & \\
\hline \multirow{8}{*}{$\begin{array}{l}\text { Entrepreneurial } \\
\text { Intention adalah } \\
\text { representasi dari } \\
\text { tindakan yang } \\
\text { direncanakan untuk } \\
\text { melakukan perilaku } \\
\text { kewirausahaan }\end{array}$} & Memiliki niat untuk membuat sebuah usaha & \multirow{8}{*}{$\begin{array}{l}\text { Hartono \& } \\
\text { Puspitowati (2019); } \\
\text { Surya \& Sitepu } \\
(2019) \text {; Trivedi } \\
(2016)\end{array}$} \\
\hline & Memiliki keinginan dalam memulai sebuah usaha & \\
\hline & $\begin{array}{l}\text { Keinginan untuk menciptakan sebuah usaha dengan kemampuan } \\
\text { yang ada }\end{array}$ & \\
\hline & Melakukan perencanaan untuk memulai usaha & \\
\hline & Pencarian informasi untuk pembentukan suatu usaha & \\
\hline & Keinginan dalam memenuhi kebutuhan hidup melalui berwirausaha & \\
\hline & Meningkatkan status sosial dan harga diri sebagai wirausaha & \\
\hline & Memilih karier sebagai wirausaha & \\
\hline
\end{tabular}




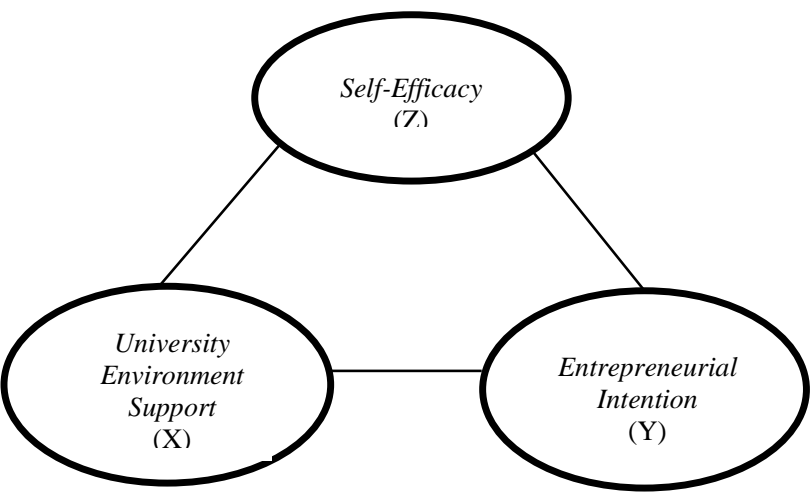

Gambar 1. Model Penelitian

Penelitian ini menggunakan Partial Least Square untuk menganalisis data. Partial Least Square adalah analisis persamaan struktural berbasis varian yang dapat melakukan pengujian model pengukuran (outer model) dan model struktural (inner model) secara simultan. model pengukuran digunakan untuk menghubungkan indikator dengan latennya, sedangkan model struktural digunakan untuk menghubungkan antar variabel laten. Penelitian ini juga menggunakan uji mediasi untuk mengetahui hubungan tidak langsung dari variabel mediasi kepada variabel independen dan variabel dependen.

\section{Model Pengukuran (Outer Model)}

model pengukuran digunakan untuk melihat hubungan antar variabel laten dengan indikatorindikatornya. Model pengukuran sendiri dibagi menjadi dua, yaitu model pengukuran reflektif dan formatif. Model pengukuran reflektif terdiri dari uji validitas dan reliabilitas.

\section{Validitas Konvergen}

Menurut Gozali \& Latan (2015), validitas konvergen berhubungan dengan prinsip bahwa pengukur-pengukur dari suatu konstruk seharusnya berkorelasi tinggi. Cara untuk menilai validitas konvergen yaitu nilai loading of factor $>$ 0,7 untuk penelitian confirmatory, 0,6-0,7 untuk penelitian exploratory dan 0,5-0,6 dianggap cukup. Sedangkan nilai average variance extracted (AVE) $>0,5$.

Validitas Diskriminan Menurut Ghozali \& Latan (2015), uji diskriminan berhubungan dengan prinsip bahwa pengukur-pengukur konstruk yang berbeda seharusnya tidak berkolerasi dengan tinggi. Cara untuk menguji validitas diskriminan yaitu dengan melihat nilai cross loading untuk setiap variabel harus $>0,70$ dan membandingkan akar kuadrat dari AVE untuk setiap konstruk dengan nilai korelasi antar konstruk dalam model.

\section{Uji Reliabilitas}

Menurut Gozali \& Latan (2015), uji reliabilitas dilakukan untuk membuktikan akurasi, konsistensi dan ketepatan instrumen dalam mengukur konstruk. Untuk mengukur uji reliabilitas dengan indikator reflektif dapat dilakukan dengan melihat cronchbach's alpha dan composite reliability. Nilai composite reliability $>0,7$ untuk penelitian confirmatory dan nilai 0,6-0,7 untuk penelitian exploratory.

\section{Model Pengukuran Formatif}

Menurut Gozali \& Latan (2015), pengukuran formatif hanya menghitung nilai variance inflation factor (VIF) dan tolerance. Dimana nilai VIF yang direkomendasikan $<10$ atau $<5$ dan nilai tolerance $>0,10$ atau $>0,20$.

\section{Model Struktural (Inner Model)}

Menurut Bimo (2011), model struktural digunakan untuk menguji hubungan antar konstruk laten. Pengujian yang terdapat di model struktural adalah sebagai berikut:

1. Uji $R^{2}$ dapat digunakan untuk mengetahui adanya pengaruh variabel laten eksogen terhadap variebel laten endogen. Nilai $R^{2}$ memiliki tiga tingkatan, yaitu 0,75 (kuat), 0,50 (moderat), dan 0,25 (lemah)

2. Uji $f^{2}$ digunakan untuk mengukur besar atau kecilnya pengaruh variabel laten terhadap level struktural. Uji $f^{2}$ terdiri dari tiga tingkatan, yaitu 0,02 (kecil), 0,15 (menengah), dan 0,35 (besar)

3. Uji Goodness of Fit (GOF)Uji GOF digunakan untuk memvalidasi model pengukuran, model struktural dan untuk keseluruhan model. Uji GOF terdiri dari tiga tingkatan, yaitu 0,1 (GOF Small), 0,25 (GOF Medium), dan 0,36 (GOF Large)

Uji Efek Mediasi

Menurut Bimo (2011), dasar analisis yang melibatkan variabel mediator (M) apabila variabel eksogen (independen) mampu mempengaruhi variabel endogen (dependen). Menurut Ghozali \& Latan (2015), indikator konstruk dalam model akan dikatakan valid apabila nilai t-statistics yang dihasilkan > 1,96. 


\section{Uji Hipotesis}

Uji hipotesis menggunakan p-value untuk menguji signifikansi antar konstruk setiap jalur. Nilai signifikansi yang digunakan (two-tailed) tstatistics >1,96 (signifikansi level $=5 \%$ ). Hipotesis antar konstruk akan dikatakan signifikan ketika nilai t-statistics $>1,96$ dan nilai p-value $<0,05$ (Gozali \& Latan,2015)

\section{ANALISIS DATA DAN PEMBAHASAN}

\section{Statistik Deskriptif}

Hasil statistik deskriptif untuk digunakan untuk mengetahui setiap nilai rata-rata indikator dan standar deviasi. Nilai rata -rata dari setiap indikator dari university environment support diatas 4 dan nilai standar deviasi yang tidak melebihi nilai sebesar 1 .

\section{Tabel 2. Statistik Deskriptif X1}

\begin{tabular}{|c|c|c|c|}
\hline Ind & Pernyataan & Mean & STEV \\
\hline $\mathrm{X} 1.1$ & $\begin{array}{l}\text { Universitas menyediakan } \\
\text { pembelajaran terkait } \\
\text { pembentukan bisnis }\end{array}$ & 4,39 & 0,66 \\
\hline X1.2 & $\begin{array}{l}\text { Universitas dapat } \\
\text { mempengaruhi } \\
\text { pertumbuhan dan } \\
\text { perkembangan } \\
\text { mahasiswa dalam } \\
\text { berwirausaha melalui } \\
\text { proses inovasi bisnis }\end{array}$ & 4,23 & 0,75 \\
\hline $\mathrm{X} 1.3$ & $\begin{array}{l}\text { Universitas membantu } \\
\text { mengembangkan network } \\
\text { mahasiswa melalui } \\
\text { company visit dan } \\
\text { pameran bisnis }\end{array}$ & 4,26 & 0,75 \\
\hline $\mathrm{X} 1.4$ & $\begin{array}{l}\text { Universitas membantu } \\
\text { mahasiswa dalam } \\
\text { menambah pengalaman } \\
\text { berupa praktik yaitu } \\
\text { melakukan eksekusi } \\
\text { bisnis }\end{array}$ & 4,43 & 0,63 \\
\hline X1.5 & $\begin{array}{l}\text { Universitas membantu } \\
\text { menumbuhkan prinsip } \\
\text { serta kepercayaan diri }\end{array}$ & 3,98 & 0,86 \\
\hline
\end{tabular}

\begin{tabular}{|c|c|c|c|}
\hline & $\begin{array}{l}\text { mahasiswa melalui } \\
\text { mentoring }\end{array}$ & & \\
\hline X1.6 & $\begin{array}{l}\text { Universitas memotivasi } \\
\text { mahasiswa dalam } \\
\text { merintis sebuah bisnis } \\
\text { melalui tahap mentoring }\end{array}$ & 4,15 & 0,81 \\
\hline $\mathrm{X} 1.7$ & $\begin{array}{l}\text { Universitas menyadarkan } \\
\text { mahasiswa pilihan karier }\end{array}$ & 4,28 & 0,70 \\
\hline
\end{tabular}

Nilai rata -rata dari setiap indikator dari self efficacy diatas 4 dan nilai standar deviasi yang tidak melebihi nilai sebesar 1 .

Tabel 3. Statistik Deskriptif Z

\begin{tabular}{|c|c|c|c|}
\hline Ind & Pernyataan & Mean & STEV \\
\hline Z1.1 & $\begin{array}{l}\text { kontrol atas diri sendiri } \\
\text { dalam berwirausaha }\end{array}$ & 4,34 & 0,77 \\
\hline $\mathrm{Z} 1.2$ & $\begin{array}{l}\text { komitmen yang tinggi } \\
\text { dalam berwirausaha }\end{array}$ & 4,23 & 0,85 \\
\hline Z1.3 & $\begin{array}{l}\text { kematangan mental } \\
\text { dalam berwirausaha }\end{array}$ & 4,01 & 0,88 \\
\hline Z1.4 & $\begin{array}{l}\text { motivasi yang kuat dalam } \\
\text { berwirausaha }\end{array}$ & 4,34 & 0,75 \\
\hline Z1.5 & $\begin{array}{l}\text { berani mengambil resiko } \\
\text { dalam berwirausaha }\end{array}$ & 4,05 & 0,87 \\
\hline Z1.6 & $\begin{array}{l}\text { Keyakinan pada } \\
\text { kemampuan yang } \\
\text { dimiliki untuk } \\
\text { berwirausaha }\end{array}$ & 4,20 & 0,76 \\
\hline Z1.7 & $\begin{array}{l}\text { Rasa percaya diri akan } \\
\text { kemampuan yang } \\
\text { dimiliki dalam memulai } \\
\text { dan mengelola bisnis }\end{array}$ & 4,27 & 0,77 \\
\hline
\end{tabular}

Nilai rata -rata dari setiap indikator dari entrepreneur intention diatas 4,45 dan nilai standar deviasi yang tidak melebihi nilai sebesar 1 . Hal ini menandakan mayoritas responden berminat untuk menjadi seorang wirausaha.

Tabel 4. Statistik Deskriptif Y

\begin{tabular}{clll}
\hline Ind & \multicolumn{1}{c}{ Pernyataan } & Mean & STEV \\
\hline Y1.1 & $\begin{array}{l}\text { niat untuk membuat } \\
\text { sebuah usaha di masa } \\
\text { depan }\end{array}$ & 4,52 & 0,67 \\
Y1.2 & $\begin{array}{l}\text { keinginan dalam } \\
\text { memulai sebuah usaha di } \\
\text { masa depan }\end{array}$ & 4,44 & 0,70 \\
Y1.3 & $\begin{array}{l}\text { keinginan untuk } \\
\text { menciptakan sebuah }\end{array}$ & 4,45 & 0,68 \\
\hline
\end{tabular}


usaha dengan

kemampuan yang ada

Y1.4 melakukan perencanaan untuk memulai sebuah usaha

Y1.5 mencari informasi untuk 4,48 $\quad 0,59$ memulai sebuah usaha

Y1.6 memenuhi kebutuhan hidup melalui berwirausaha

\begin{tabular}{llcc}
\hline Y1.7 & $\begin{array}{l}\text { meningkatkan status } \\
\text { sosial dan harga diri } \\
\text { sebagai wirausaha } \\
\text { memilih karier sebagai } \\
\text { Y1.8 }\end{array}$ & 4,34 & 0,82 \\
& $\begin{array}{l}\text { wirausaha dibandingkan } \\
\text { bekerja kepada orang lain }\end{array}$ & & 0,80 \\
\hline
\end{tabular}
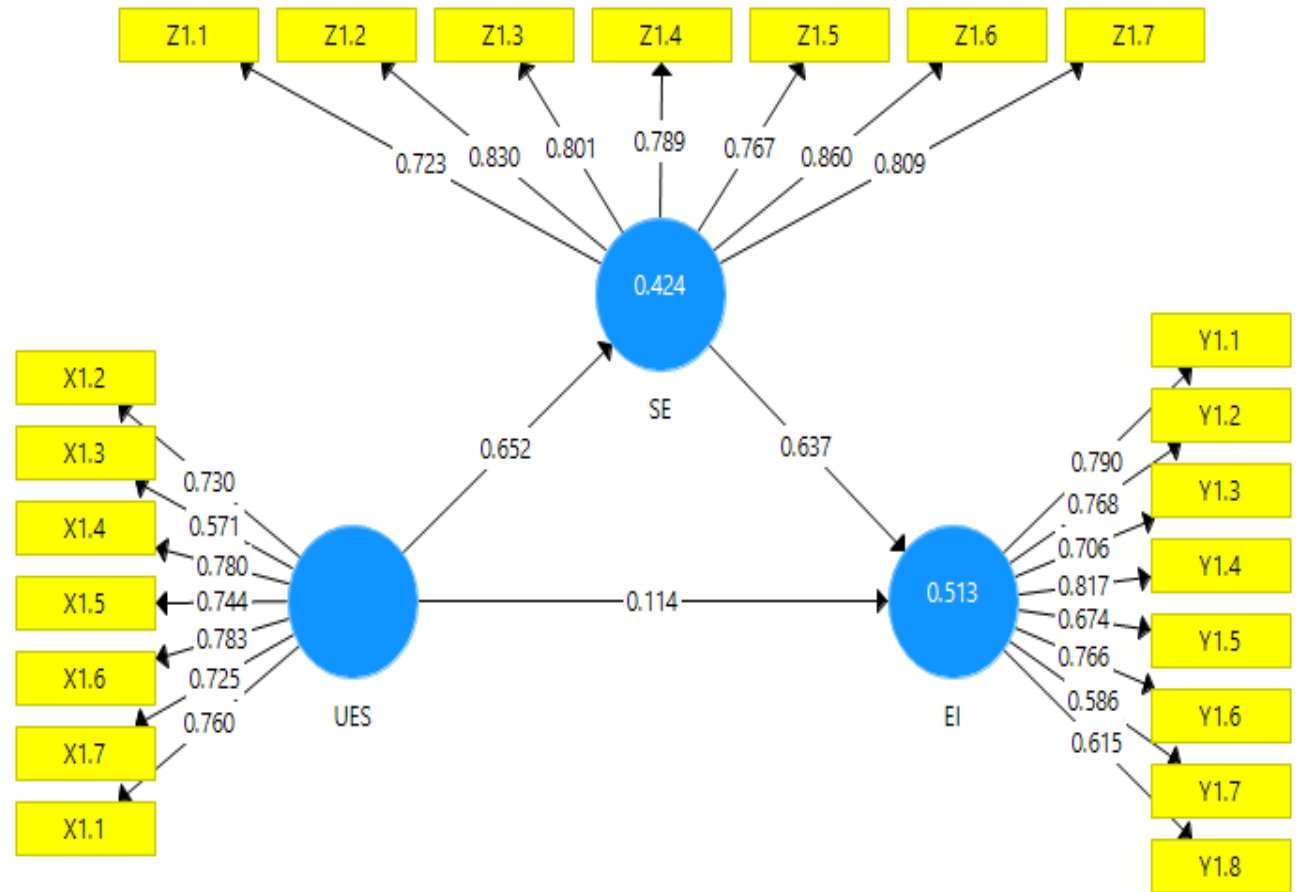

Gambar 2 Model Outer Loading

Sumber: Partial Least Square

\section{Evaluasi Model Pengukuruan Formatif}

Pengukuran formatif dihitung dengan menggunakan nilai variance inflation factor (VIF) $<10$ atau $<5$ dan nilai tolerance $>0,10$ atau $>0,20$ (Ghozali \& Latan, 2015). Berdasarkan hasil penelitian yang tertera pada tabel variance inflation factor (VIF) dibawah, maka semua variabel dengan konstruk formatif dinyatakan valid karena telah memenuhi syarat.

Tabel 8. VIF

\begin{tabular}{ccc}
\hline & VIF & Keterangan \\
\hline $\mathrm{X} 1.1$ & 2,124 & \\
$\mathrm{X} 1.2$ & 2,032 & \\
$\mathrm{X} 1.3$ & 1,398 & \\
$\mathrm{X} 1.4$ & 1,908 & Valid \\
$\mathrm{X} 1.5$ & 1,772 & \\
\hline
\end{tabular}

$\mathrm{X} 1.6$

$\mathrm{X} 1.7$ 1,838

$\mathrm{Z} 1.1$ 1,652

$\mathrm{Z} 1.2$ 1,798

Z1.3 2,440

Z1.4 2,334

Z1.5

2,249

2,189

Z1.6 2,919

$\mathrm{Z} 1.7 \quad 2,363$

Y1.1 2,320

Y1.2 1,959

Y1.3 1,870

Y1.4 2,419

Y1.5 1,694

Y1.6 2,208

Y1.7 1,463

Y1.8

1,483 


\section{Evaluasi Model Struktural}

Evaluasi model struktural digunakan untuk menguji hubungan antar konstruk laten.

Pengujian yang terdapat di model struktural adalah uji $R^{2}$ dan uji $f^{2}$. Nilai $R^{2}$ pada variabel entrepreneurial intention memiliki hasil yang moderat yaitu 0,513 dan self-efficacy memiliki hasil yang lemah yaitu 0,424 . Namun pada uji GOF, nilai $R^{2}$ dianggap large karena memiliki nilai diatas 0,36 dengan rata-rata 0,469 . Nilai $f^{2}$ antara university environment support dan selfefficacy memiliki hasil yang besar pada nilai 0,480, self-efficacy dan entrepreneurial intention memiliki hasil yang juga besar pada nilai 0,738 namun university environment support dan entrepreneurial intention memiliki hasil yang kecil dengan nilai 0,051 .

\section{Uji $R^{2}$}

Nilai $R^{2}$ memiliki tiga tingkatan, 0,75 (kuat), 0,50 (moderat), dan 0,25 (lemah) (Ghozali \& Latan, 2015). Berdasarkan hasil penelitian yang tertera pada tabel $R^{2}$ dibawah, menunjukkan bahwa nilai $R^{2}$ pada variabel self-efficacy memiliki hubungan antara variabel eksogen dan edogen yang tergolong lemah dengan nilai 0,424. Sedangkan untuk variabel entrepreneurial intention memiliki hubungan moderat dengan nilai 0,513 .

Tabel 9. Uji $R^{2}$

\begin{tabular}{ccc}
\hline & $\boldsymbol{R}^{\mathbf{2}}$ & Keterangan \\
\hline $\begin{array}{c}\text { Entrepreneurial } \\
\text { Intention }\end{array}$ & 0,513 & Moderat \\
Self-Efficacy & 0,424 & Lemah \\
\hline
\end{tabular}

Sumber: Data Diolah

\section{$\mathrm{Uji} \boldsymbol{f}^{2}$}

Uji $f^{2}$ memiliki tiga tingkatan, 0,02 (kecil), 0,15 (menengah), dan 0,35 (besar) (Ghozali \& Latan, 2015). Berdasarkan hasil penelitian yang tertera pada tabel $f^{2}$ dibawah, maka diketahui bahwa:

1. University environment support sebagai variabel eksogen memiliki pengaruh yang besar terhadap variabel self-efficacy pada tingkat struktural, yaitu 0,480 .

\section{Uji Hipotesis}

Pengujian hipotesis dilakukan dengan menggunakan partial least square dan
2. Self-efficacy sebagai variabel eksogen memiliki pengaruh yang besar terhadap entrepreneurial Intention pada tingkat struktural, yaitu 0,738.

3. University envioronment support sebagai variabel eksogen memiliki pengaruh yang sangat kecil terhadap variabel entrepreneurial intention pada tingkat struktural, yaitu 0,051 .

Tabel 10. Uji $f^{2}$

\begin{tabular}{|c|c|c|}
\hline & $f^{2}$ & Keterangan \\
\hline $\begin{array}{c}\text { University } \\
\text { Environment Support - } \\
\text { Self-Efficacy }\end{array}$ & 0,480 & Besar \\
\hline $\begin{array}{l}\text { Self-Efficacy - } \\
\text { Entrepreneurial } \\
\text { Intention }\end{array}$ & 0,738 & Besar \\
\hline $\begin{array}{c}\text { University } \\
\text { Environment Support - } \\
\text { Entrepreneurial } \\
\text { Intention }\end{array}$ & 0,051 & Kecil \\
\hline
\end{tabular}

Sumber: Data Diolah

Dari tabel diatas menunjukkan tingkatan dari besar atau kecilnya pengaruh variabel laten terhadap level structural. Hasil menunjukkan tingkatan pada tingkat besar dan kecil untuk hubungan dari variabel university environment support, self efficacy, dan entrepreneurial intention.

\section{Uji Goodness of Fit (GOF)}

Uji GOF memiliki tiga tingkatan, 0,1 (GOF Small), 0,25 (GOF Medium), dan 0,36 (GOF Large) (Ghozali \& Latan, 2015). Dari hasil perhitungan nilai GOF pada tabel dibawah, maka model struktural dari penelitian ini dinyatakan valid dan memiliki hubungan yang besar atau kuat karena bernilai 0,469 .

Tabel 10. Perhitungan Nilai GOF

\begin{tabular}{ccc}
\hline & $\boldsymbol{R}^{\mathbf{2}}$ & Keterangan \\
\hline Self-Efficacy & 0,424 & Large \\
Entrepreneurial & 0,513 & Large \\
Intention & & \\
Rata-rata & 0,469 & Large \\
\hline
\end{tabular}

mendapatkan hasil jika Pengaruh university environment support $(\mathrm{X})$ berpengaruh terhadap self-efficacy $(Z)$ secara signifikan. Demikian juga 
Pengaruh self efficacy $(Z)$ berpengaruh secara signifikan terhadap entrepreneurial intention $(Y)$. Hasil berbeda ditemukan Pengaruh university environment support $(X)$ yang tidak berpengaruh signifikan terhadap entrepreneurial intention $(Y)$.
Hasil uji efek mediasi menemukan efek full mediasi dimana varaibel self efficacy memdiasi pengaruh university environment support terhadap entrepreneurial intention

Tabel 11. Hasil Analisis

\begin{tabular}{|c|c|c|c|c|c|}
\hline Hipotesis & Koefisien & t-statistics & p-value & Signifikan & Keterangan \\
\hline Pengaruh Langsung & & & & & \\
\hline $\begin{array}{c}\text { University Environment Support - Self- } \\
\text { Efficacy }\end{array}$ & 0,652 & 7,149 & 0,00 & Signifikan & Diterima \\
\hline $\begin{array}{l}\text { University Environment Support- } \\
\text { Entrepreneurial Intention }\end{array}$ & 0,114 & 0,958 & 0,316 & $\begin{array}{l}\text { Tidak } \\
\text { Signifikan }\end{array}$ & Ditolak \\
\hline $\begin{array}{l}\text { Self-Efficacy - Entrepreneurial Intention } \\
\text { Pengaruh Tidak Langsung }\end{array}$ & 0,637 & 6,162 & 0,00 & Signifikan & Diterima \\
\hline $\begin{array}{c}\text { Self-Efficacy sebagai mediasi University } \\
\text { Environment Support - Entrepreneurial } \\
\text { Intention }\end{array}$ & 0,415 & 4,283 & 0,00 & Signifikan & Diterima \\
\hline
\end{tabular}

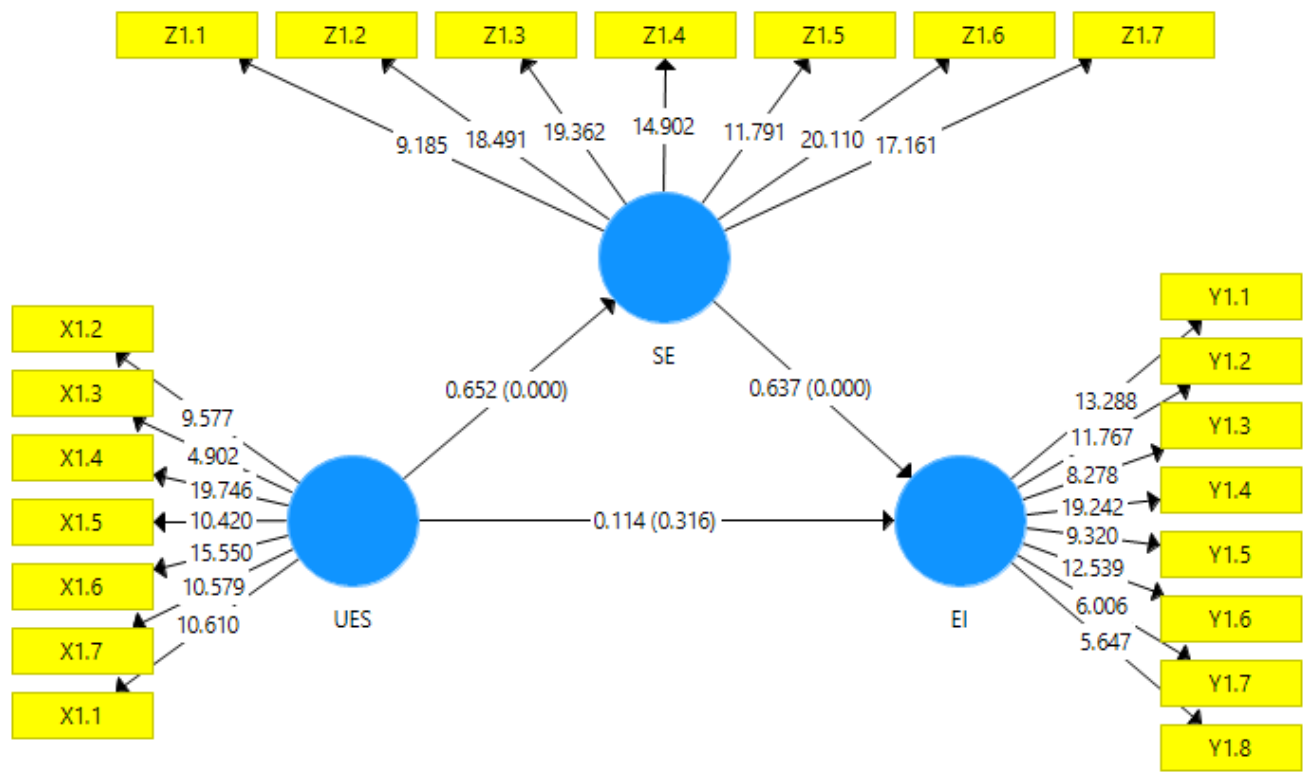

Gambar 3 Model Signifikansi

Sumber: Partial Least Square

\section{Pembahasan}

Pengaruh university environment support terhadap self-efficacy membuktikan bahwa pembelajaran dan praktik yang diberikan di lingkungan pendidikan universitas melalui mata kuliah entrepreneurship mampu menumbuhkan self-efficacy mahasiswa. Melalui mata kuliah entrepreneurship ini dapat melatih dan mempersiapkan mahasiswa sebelum mereka benar-benar terjun ke dunia entrepreneur di masa yang akan datang. Mahasiswa diberikan pembelajaran terkait pembentukan dan perencanaan bisnis seperti pembuatan business model canvas, membuat SWOT analysis, membuat laporan keuangan dan pembelajaran terkait pemasaran. Pada pembelajaran entrepreneurship dalam ruang lingkup universitas ini mahasiswa dibimbing oleh para ahli dalam bentuk mentoring yang dapat membantu mahasiswa dalam mencapai target 
dan tujuan pembelajaran. Melalui proses mentoring, diharapkan dapat menumbuhkan kepercayaan diri serta memotivasi mahasiswa dalam berwirausaha. Dukungan yang diberikan oleh Universitas dalam proses Pendidikan secara keseluruhan diharapkan dapat membantu menciptakan kesadaran mahasiswa dalam berwirausaha sebagai pilihan karier. Selain itu, kesadaran mahasiswa dalam berwirausaha juga dapat dikembangkan melalui seminar dan kuliah tamu yang diselenggarakan oleh universitas (Surya \&Sitepu, 2019). Praktik yang diberikan kepada mahasiswa seperti melakukan eksekusi bisnis, pembentukan inovasi, mengembangkan performa bisnis di pasar global, mengikuti atau mendatangi pameran bisnis dan melakukan company visit. Hasil penelitian ini sesuai dengan penelitian (Trivedi, 2016) dan (Surya \& Sitepu, 2019). University environment support tidak berpengaruh terhadap entrepreneurial intention mahasiswa. Hal ini menunjukkan bahwa baik atau buruk university environment support tidak akan menimbulkan entrepreneurial intention mahasiswa. Hasil penelitian ini sesuai dengan penelitian (Wati et al., 2019). Salah satu contoh yang diberikan sebagai dukungan adalah secara tidak langsung membantu mahasiswa dalam melihatkan peluang usaha yang ada akan tetapi tingkat minat mahasiswa dalam berwirausaha bisa dibilang cukup rendah. Dalam university environment support ada keahlian kompetensi yang tidak bisa disampaikan secara langsung sebagai conton yaitu pengenalan peluang usaha. Mahasiswa yang belum memiliki kemampuan untuk mengenali peluang usaha secara positif akan terkendala pada ide penciptaan usaha (Song et al., 2017). Keahlian mengenali peluang perlu proses yang dilakukan oleh mahasiswa yang dipelajari dengan melakukan analisis situasi dan proses mentoring sehingga yakin akan adanya sebuah peluang (Puni et al., 2018). Hal ini bisa disebabkan juga dari latar belakang demografi yang berasal dari kelangan keluarga cukup sehingga dapat menyebabkan belum ada pemikiran untuk bekerja dan memenuhi kebutuhan hidupnya sendiri. Hal ini menyebabkan upaya universitas yang diberikan kepada mahasiswa tidak secara efektif dapat menumbuhkan intensi mahasiswa. Pengaruh self-efficacy terhadap entrepreneurial intention membuktikan bahwa mahasiswa yang memiliki self-efficacy yang tinggi lebih memiliki kesiapan dalam berwirausaha (Vanessa \& Sienatra, 2020). Kesiapan ini baik dari segi mental maupun tindakan yang akan dilakukan. Pendidikan universitas telah berhasil menumbuhkan kepercayaan diri mahasiswa melalui pembelajaran dan praktik yang diberikan selama perkuliahan yang juga disebut sebagai sistem pembelajaran project-basedlearning. Melalui sistem pembelajaran ini, mahasiswa dapat secara langsung merasakan pengalaman dalam berwirausaha sehingga mental dan self-efficacy mereka dalam berwirausaha juga sudah sangat siap. Mahasiswa sendiri yang memiliki rasa percaya diri yang kuat pada kemampuan yang dimiliki dalam memulai dan mengelola bisnisnya sendiri termasuk dalam mencapai tujuan dan menyelesaikan masalah yang ada pada bisnis. Kepercayaan diri dalam diri seseorang membuat mereka mampu untuk menghadapi suatu masalah yang muncul, mencari solusi untuk mengatasinya dan menyelesaikan tugas untuk mencapai sebuah tujuan (Puspitaningtyas, 2017). Hasil penelitian ini sesuai dengan penelitian Oktaviana \& Umami (2018) Khotimah et al. (2017)

Pengaruh university environment support terhadap entrepreneurial intention melalui mediasi self-efficacy membuktikan bahwa entrepreneurial intention mahasiswa tidak akan langsung muncul secara langsung dimana harus ada dorongan dan dukungan baik dari dalam maupun luar individu. Dukungan dari luar individu dapat didapatkan melalui university environment support dimana Pendidikan universitas menerapkan sistem pembelajaran project-based-learning yang membuat mahasiswa dapat merasakan secara langsung bagaimana sebuah bisnis berjalan. Seseorang yang memiliki tingkat self-efficacy yang tinggi, biasanya cenderung untuk yakin akan kemampuan dan kompetensi dirinya dalam melakukan sesuatu yang menjadi tujuannya termasuk untuk menjadi seorang entrepreneur. Seseorang yang memiliki tingkat self-efficacy yang rendah cenderung untuk ragu dalam bertindak sehingga mereka tidak dapat mencapai tujuannya. Mahasiswa yang rata-rata memiliki tingkat self-efficacy yang tinggi dimana mereka yakin pada kemampuan yang dimilikinya untuk berwirausaha. Mahasiswa 
merasa bahwa pembelajaran dan pengalaman yang diberikan oleh lingkungan universitas kepada mereka sudah dapat membangun selfefficacy masing-masing individu dalam berwirausaha. Hal ini membuat entrepreneurial intention mereka meningkat. Hal ini membuat tercipta dan meningkatnya self-efficacy mahasiswa dalam berwirausaha. Mahasiswa yang memiliki self-efficacy yang tinggi cenderung untuk memiliki entrepreneurial intention. Hal ini disebabkan karena mereka percaya akan kemampuan yang dimiliki untuk melakukan wirausaha di masa yang akan datang. Hasil penelitian ini sesuai dengan penelitian Trivedi (2016).

Sampel dalam penelitian ini yang merupakan mahasiswa jurusan bisnis memiliki niatan untuk berwirausaha di masa yang akan datang. Sebagian besar dari mereka lebih memilih untuk memulai dan mengelola bisnisnya sendiri dibandingkan mencari pengalaman terlebih dahulu dengan bekerja kepada orang lain. Hal ini menunjukkan bahwa entrepreneurial intention mahasiswa sangat tinggi sampai-sampai mereka kurang tertarik untuk mencari pengalaman bekerja. Secara tidak langsung, kita dapat mengetahui bahwa selfefficacy mahasiswa sangat tinggi dengan kemampuan yang dimiliki sehingga mereka berani untuk membuka bisnisnya sendiri walaupun belum ada pengalaman bekerja yang cukup banyak.

\section{Implikasi Hasil Penelitian}

Universitas telah melakukan beberapa hal sebagai dukungan university environment support terhadap entrepreneurial intention mahasiswa namun upaya tersebut kurang efektif. Hal ini dikatakan kurang efektif karena apapun bentuk dukungan yang diberikan Universitas tidak dapatsecara langsung menumbuhkan entrepreneurial intention mahasiswa. Pada dasarnya, entrepreneurial intention akan tumbuh apabila seseorang telah memiliki jiwa kewirausahaan didalam diri mereka. Jiwa kewirausahaan tersebut meliputi seseorang yang memiliki motivasi yang tinggi, pekerja keras, memiliki jiwa kepemimpinan, bertanggung jawab, berani mengambil resiko serta percaya akan kemampuan yang dimiliki atau bisa disebut dengan self-efficacy. Seseorang 68 yang telah memiliki jiwa kewirausahaan tersebut cenderung untuk memiliki entrepreneurial intention

Dalam mendukung tumbuhnya jiwa kewirausahaan, Universitas menyediakan program kepada mahasiswa yang disebut sebagai leadership. Program ini merupakan kegiatan yang diikuti oleh mahasiswa selama empat hari. Melalui leadership ini mahasiswa diberikan pembekalan terkait jiwa kewirausahaan seperti bagaimana untuk menjadi seorang pemimpin yang baik, cara menempatkan diri dan berperilaku dalam suatu tim, mengajarkan untuk memiliki integritas yang tinggi dan berani mengambil keputusan dalam suatu organisasi. Pada dasarnya, leadership ingin menumbuhkan jiwa kewirausahaan dalam diri seseorang agar dapat meningkatkan entrepreneurial intention mereka.

Universitas juga dapat menumbuhkan jiwa kewirausahaan mahasiswa melalui beberapa kegiatan yang melibatkan interaksi antara mahasiswa dan pengusaha di luar kampus. Pertama dapat dilakukan melalui pameran bisnis yang membuka peluang kerjasama terhadap bisnis mahasiswa. Melalui pameran bisnis tersebut, mahasiswa akan merasa termotivasi dalam menjalankan bisnisnya, berusaha lebih keras lagi guna menumbuhkan bisnis yang sedang dikelola, memiliki tanggung jawab terhadap bisnis dan partner bisnis serta berani mengambil resiko dalam keputusan yang diambil.

Kedua, jiwa kewirausahaan dapat dikembangkan melalui company visit yang menawarkan peluang kerjasama terhadap bisnis mahasiswa. Hal ini sama seperti pameran bisnis dimana mahasiswa yang diberikan kesempatan dalam bekerjasama dengan perusahaan lain pasi akan lebih termotivasi lagi dalam menjalankan bisnisnya, berusaha semaksimal mungkin untuk hasil yang lebih baik serta bertanggung jawab atas suatu hal. Hal ini dilakukan karena tentu saja mahasiswa ingin memberikan yang terbaik bagi partner bisnisnya.

\section{SIMPULAN DAN SARAN}

Pendidikan universitas telah melakukan beberapa hal sebagai dukungan university 
environment support terhadap entrepreneurial intention mahasiswa namun upaya tersebut kurang efektif. Pada dasarnya, apapun bentuk dukungan yang diberikan oleh Pendidikan universitas tidak dapat secara langsung menumbuhkan entrepreneurial intention mahasiswa. Entrepreneurial intention akan tumbuh apabila seseorang memiliki jiwa kewirausahaan didalam diri mereka. Jiwa kewirausaah tersebut meliputi seseorang yang memiliki motivasi yang tinggi, pekerja keras, memiliki jiwa kepemimpinan, bertanggung jawab, berani mengambil resiko serta percaya akan kemampuan yang dimiliki (self-efficacy). Beberapa cara yang dapat dilakukan oleh Pendidikan universitas guna menumbuhkan jiwa kewirausahaan dapat melalui program leadership 101, pameran bisnis dan company visit. Melalui kegiatan tersebut dipercaya dapat membuat mahasiswa memiliki jiwa kewirausahaan yang tentunya dapat meningkatkan entrepreneurial intention mereka. Hasil penelitian ini menunjukkan adanya pengaruh yang signifikan dan tidak signifikan. University environment support berpengaruh secara signifikan terhadap selfefficacy mahasiswa dimana pembelajaran dan praktik yang diberikan oleh pendidikan universitas mampu menumbuhkan self-efficacy mahasiswa. University environment support tidak berpengaruh secara signifikan terhadap entrepreneurial intention mahasiswa. Hal ini menunjukkan bahwa baik atau buruk dukungan yang diberikan oleh universitas tidak akan menimbulkan entrepreneurial intention mahasiswa. Dapat disimpulkan bahwa upaya dalam bentuk apapun tidak secara efektif dapat menumbuhkan intensi mahasiswa dalam berwirausaha. Self-efficacy berpengaruh secara signifikan terhadap entrepreneurial intention mahasiswa dimana mahasiswa yang memiliki kepercayaan diri cenderung untuk memiliki kesiapan dalam berwirausaha. Hal ini menunjukkan bahwa Pendidikan universitas dapat menumbuhkan intensi mahasiswa melalui self-efficacy. Pengaruh university environment support terhadap entrepreneurial intention melalui self-efficacy menunjukkan pengaruh yang signifikan. Hal ini menunjukkan bahwa dukungan yang diberikan oleh lingkungan pendidikan universitas melalui praktik dan pembelajaran mampu menumbuhkan self- efficacy mahasiswa. Mahasiswa yang memiliki self-efficacy pada dirinya akan memiliki intensi dalam berwirausaha. Berdasarkan penelitian, university environment support tidak dapat mempengaruhi entrepreneurial intention mahasiswa secara langsung sehingga Pendidikan universitas disarankan untuk dapat meningkatkan entrepreneurial intention mahasiswa melalui self-efficacy terlebih dahulu melalui improvisasi pembelajaran dan praktik yang lebih difokuskan. Mahasiswa disarankan untuk dapat menggunakan kesempatan yang diberikan oleh Pendidikan universitas dengan sebaik mungkin dan diharapkan dapat menjalani bisnis sesuai dengan ketertarikan mereka dalam berwirausaha. Penelitian selanjutnya disarankan untuk dapat menambah jumlah sampel yang lebih banyak untuk memperkuat hasil penelitian secara maksimal dan dapat menambah teori lebih banyak untuk dapat mendukung penelitian yang dilakukan.

\section{DAFTAR PUSTAKA}

Abdi, H. (2019, Maret 25). Ini 6 Cara Mengatasi Pengangguran, dari Pendidikan hingga Transmigrasi. Retrieved from Liputan 6: https://www.liputan6.com/citizen6/read/3 922461/ini-6-cara-mengatasipengangguran-dari-pendidikan-hinggatransmigrasi(2018), O. V. D. \& U. N. (2018). Pengaruh Efikasi Diri Dan Kreativitas Terhadap Intensi Berwirausaha Pada Siswa Kelas Xi Smk Negeri 1 Pogalan Tahun Ajaran. Jurnal Pendidikan Ekonomi. https://doi.org/10.17977/UM014v11i220 $18 \mathrm{p} 080$

Ajzen, I. (1991). The theory of planned behavior. Organizational Behavior and Human Decision Processes. https://doi.org/10.1016/07495978(91)90020-T

Fauzani, F., Suryani, S., \& Rahmawati, R. (2019). Peran Academic, Social dan Environment Support pada Intensi Berwirausaha Mahasiswa. SERAMBI: Jurnal Ekonomi Manajemen Dan Bisnis Islam. https://doi.org/10.36407/serambi.v1i3.13 3 
Gelaidan, H. M., \& Abdullateef, A. O. (2017). Entrepreneurial intentions of business students in Malaysia: The role of selfconfidence, educational and relation support. Journal of Small Business and Enterprise Development. https://doi.org/10.1108/JSBED-06-20160078

Gozali, I., \& Latan, H. (2015). Patrial Least Squeres Konsep, Teknik, dan Aplikasi Menggunakan Program SmartPLS3.0. In Semarang: UNDIP. https://doi.org/10.9744/jmk.21.1.1-8

Hartono, J., \& Puspitowati, I. (2019). Pengaruh Attitude, Subjective Norms Dan Self Efficacy Terhadap Intensi Berwirausaha Pada Mahasiswa Fakultas Ekonomi Universitas Tarumanagara. Jurnal Manajerial Dan Kewirausahaan.

Kusmintarti, A., Riwajanti, N. I., \& Asdani, A. (2017). Pendidikan Kewirausahaan dan Intensi Kewirausahaan dengan Sikap Kewirausahaan sebagai Mediasi. Journal of Research and Applications: Accounting and Management. https://doi.org/10.18382/jraam.v2i2.160

Puni, A., Anlesinya, A., \& Korsorku, P. D. A. (2018). Entrepreneurial education, selfefficacy and intentions in Sub-Saharan Africa. African Journal of Economic and Management Studies. https://doi.org/10.1108/AJEMS-09-20170211

Puspitaningtyas, Z. (2017). Pengaruh Efikasi Diri Dan Pengetahuan Manajemen Keuangan Bisnis Terhadap Intensi Berwirausaha. Jurnal Wira Ekonomi Mikroskil.

Rizki, Q. G., \& Megawati. (2019). Pengaruh Faktor Dukungan Universitas Dan Kepribadian Proaktif Terhadap Intensi Berwirausaha Pada Mahasiswa S1 Fakultas Ekonomi Dan Bisnis Universitas Syiah Kuala. Jurnal Ilmiah Mahasiswa Ekonomi Manajemen.

Robbins, S. P., \& Judge, T. A. (2013). Organizational Behavior 15th Edition. In The Curated Reference Collection in Neuroscience and Biobehavioral Psychology. https://doi.org/10.1016/B978-0-12809324-5.06506-8
Santy, N., Rahmawati, T., \& Hamzah, A. (2017). PENGARUH EFIKASI DIRI, NORMA SUBJEKTIF, SIKAP BERPERILAKU DAN PENDIDIKAN KEWIRAUSAHAAN TERHADAP INTENSI BERWIRAUSAHA. Jurnal Inspirasi Bisnis Dan Manajemen. https://doi.org/10.33603/jibm.v1i1.481

Shirokova, G., Osiyevskyy, O., \& Bogatyreva, K. (2016). Exploring the intentionbehavior link in student entrepreneurship: Moderating effects of individual and environmental characteristics. European Management Journal. https://doi.org/10.1016/j.emj.2015.12.007

Sienatra, Krimsi Budi, \& Padmalia, M. (2018). Faktor-Faktor Yang Mempengaruhi Intensi Entrepreneurial Pada Siswa Dan Mahasiswa Di Surabaya. Jurnal Ilmiah Bisnis Dan Ekonomi Asia, 12(1), 32-39. https://doi.org/10.32812/jibeka.v12i1.12

Sienatra, Krismi Budi. (2020). Effects of Entrepreneurship Education as an Entrepreneurial Personality Trait Model under Entrepreneurial Intention for the Future in Surabaya. Jurnal Entrepreneur Dan Entrepreneurship, 9(1), 29-42. https://doi.org/10.37715/jee.v9i1.1191

Song, G., Min, S., Lee, S., \& Seo, Y. (2017). The effects of network reliance on opportunity recognition: A moderated mediation model of knowledge acquisition and entrepreneurial orientation. Technological Forecasting and Social Change. https://doi.org/10.1016/j.techfore.2017.0 1.004

Soria-Barreto, K., Honores-Marin, G., Gutiérrez-Zepeda, P., \& GutiérrezRodríguez, J. (2017). Prior exposure and educational environment towards entrepreneurial intention. Journal of Technology Management and Innovation. https://doi.org/10.4067/S071827242017000200006

Trivedi, R. (2016). Does university play significant role in shaping entrepreneurial intention? A cross-country comparative analysis. Journal of Small Business and Enterprise Development. https://doi.org/10.1108/JSBED-10-20150149

Wati, F. F., Sukmawati, L., \& Alamsyah, D. P. 
(2019). Pengaruh Lingkungan Kampus dan Pembelajaran Kewirausahaan terhadap Keinginan Berwirausaha (Technopreneur) pada Mahasiswa. Journal of Technopreneurship and Information System (JTIS). https://doi.org/10.36085/jtis.v2i2.147

Wulandari, S. (2013). Pengaruh Efikasi Diri Terhadap Minat Berwirausaha Pada Siswa Kelas XII Di SMK Negeri Surabaya. Fakultas Ekonomi, Unesa, Kampus Ketintang Surabaya. 